\title{
パラレルワイヤ駆動システムの 作業座標系制御法とそのロバスト性
}

\author{
木 野 \\ 仁*1 矢 部 \\ 茂*2 Chien Chern Cheah*3 \\ 川 村 貞 夫*2 有 本 卓*2
}

\section{A Motion Control Scheme in Task Oriented Coordinates and its Robustness for Parallel Wire Driven Systems}

\author{
Hitoshi Kino*1, Sigeru Yabe ${ }^{* 2}$, Chien Chern Cheah*3, \\ Sadao Kawamura*2 and Suguru Arimoto*2
}

\begin{abstract}
Parallel wire driven robots have some advantages such as high speed, heavy load and so on. In the previous works in the parallel wire driven robots, the object or the end-effector is controlled through each wire length. However, each actuator position in the base coordinates and each measured length of wires include errors. Therefore, even if fine positioning in wire length coordinates is realized, the end-effector position may deviate from a desired position in task oriented coordinates. To overcome such difficulty, we propose a new motion control scheme for the parallel wire driven robots in this paper. In the proposed scheme, a pseudo inverse matrix which shows the relation between a wire tensions vector and a force vector of the end-effector is utilized to operate the object in the task oriented coodinates. When the proposed control scheme based on the force relation is used, it is easy to attain more precise positioning by using external sensors such as cameras, and to apply it to force control. In this paper, we prove the motion convergence to desired points and discuss its robustness based on Lyapunov stability analysis. Finally the usefulness of the proposed control scheme is demonstrated through some experimental results.
\end{abstract}

Key Words: Pararell Wire, Stability, Task Oriented Coordinates, Robustness

\section{1. はじめに}

パラレルワイヤ駆動システムは単一方向駆動多自由度機械シ ステムの一種類である。単一方向駆動多自由度機械システムと は，対象物体の操作を行う際にアクチュエータからの力伝達が 引っ張りもしくは压縮のどちらかのみによって行われるもので あり，他の代表的な単一方向駆動多自由度機械システムとして は指ロボットなどが挙げられる，パラレルワイヤ駆動機構はリ ンクの代わりにワイヤを利用しているのが特徽であり, ワイヤ をアクチュエータで巻き取ることによって対象物を制御する. 手先稼動部の軽量化に伴い, 構造が簡単, 並進の可動範囲が大 きい，可搬重量が大きい，高速性などの利点がある。しかしな がら，ワイヤは張力しか発生できないため， $n_{0}$ 自由度を制御 するためのワイヤ本数は $n_{0}+1$ 本以上となり, 圥長駆動系と ならざるを得ない $[1]$. また，現在このシステムと類似の方法を 利用した様々な応用が提案されている $[2] 〜[7]$.

原稿受付 1999 年 4 月 8 日

*1 滋賀医科大学マルチメディアセンタ

$* 2$ 立命館大学理工学部

$* 3$ Nanyang Technological University

${ }^{* 1}$ Multi-Media Center, Shiga University of Medical Science

${ }^{* 2}$ Faculty of Science and Engineering, Ritsumeikan University

${ }^{* 3}$ Nanyang Technological University
パラレルワイヤ駆動システムの制御法には，対象物体の位置 姿勢を各ワイヤ長さに換算する制御法と対象物体に働く力をワ イヤの張力に換算する制御法が考えられる。前者を位置制御に 利用する場合には対象物体の目標位置姿勢での目標ワイヤ長さ を算出し，これについてフィードバック制御を行えばよい.こ れは一般のロボットにおける関節角制御の方法と類似する。す でに筆者らはワイヤ座標系制御法については最少ワイヤ本数の 場合について, Vector Closureの条件を用いて目標ワイヤ長さ に収束することを証明している，さらに，実験によってその有 用性を確かめている [8]. しかしながら, 実際には逆運動学計算 にアクチュエータ配置誤差やプーリ巻き取り誤差などが存在す るため，内界センサによるフィードバックだけでは手先に位置 誤差が生じる。同様な制御法でも内界センサの代わりに外界セ ンサを用いてワイヤ座標系制御を行う場合も考えられる。これ は外界センサより得られた対象物体の位置座標から逆運動学を 用いてリアルタイムでワイヤ長さを算出し, ワイヤ長さについ てフィードバック制御を行う方法である。この方法では内界セ ンサに比べ位置誤差が少ないと考えられるが，力制御を行う場 合では有効ではない.

一方, 後者の力関係に基づく制御法はカメラなどの外界セン サを用いて対象物体の作業座標系での位置姿勢を計測し, 作業 座標系でフィードバックを行うことができる。一般のシリアル 
リンクロボットの作業座標系制御法では順運動学を時間常微分 した関係から得られたヤコビ行列 $J$ の転置行列 $J^{T}$ を用いる 方法が広く知られている [9]. また， $J^{T}$ は関節トルクと手先発 生力を関係付けるヤコビ行列であるので, 力制御への拡張も容 易である。しかし，パラレルワイヤ駆動システムについて $J^{T}$ 制御方法に対応する制御方式は提案されていない.

そこで本論文ではパラレルワイヤ駆動システムの作業座標系 制御法としてワイヤ行列 $W$ の擬似逆行列 $W^{+}$を用いた方法を 提案する. ワイヤ行列 $W$ はワイヤ張力ベクトルを対象物体発 生力ベクトルに変換する行列であり, 原理的には力の関係を用 いるという点では $J^{T}$ の方法と同じであるが, ワイヤ行列 $W$ は非正方行列であるので, 対象物体発生力ベクトルからワイヤ 張力ベクトルを求めるには擬似逆行列 $W^{+}$が必要となる。こ の方法は作業座標系で直接フィードバックするため, 内界セン サを利用した関節座標系制御法に比べて高精度の位置決めが容 易であり，アクチュエータ配置誤差に対するロバスト性も高い と期待される。 また, 力制御への応用が可能であるので, 有効 な制御法の一つと考えられる，以下では，はじめにリアプノフ の方法で安定性について論じ，ワイヤ行列に誤差を含む場合に ついてのロバスト性について解析を行う.さらに実際に 4 本ワ イヤを用いた平面 3 自由度ロボットにおいて，外界センサを用 いた位置制御と力制御を行い, 本制御法の性能とロバスト性を 確認する.

\section{2. システムダイナミクス}

以下においては一般的な $m$ 本ワイヤを用いて $n_{0}\left(m>n_{0}\right)$ 自由度制御について説明する。たたし, ワイヤの質量, 空気抵 抗, アクチュエータワイヤ出口に設置されている小型ガイド プーリの方向による慣性の変化はその他の要素に比べ非常に 微小であり無視できるものとする．使用するワイヤとアクチュ エー夕はわずかに非線形バネ要素を有しているが，ここでは考 慮しない.以下の制御では制御対象物は常に許容動作空間内に あり，Vector Closure [1] [8] を満足すると仮定する。また，十 分大きな内力を発生できるものとし, 制御を行う場合は常にワ イヤに張力を与えながら制御できるものとする。このような仮 定のもとに駆動系ダイナミクスは次式で表すことができる.

$$
M \ddot{q}+B \dot{q}=\tau-\alpha_{t}
$$

$$
\begin{aligned}
& \text { ただし } \\
& q=\left(q_{1}, q_{2}, \ldots, q_{m}\right)^{T} \in R^{m}: \text { ワイヤ長さベクトル } \\
& M=\operatorname{diag} .\left(a_{1}, a_{2}, \ldots, a_{m}\right) \in R^{m \times m}: \text { 駆動系慣性行列 } \\
& a_{i}: i \text { 番目駆動部の慣性定数 }\left(a_{i}>0\right) \\
& B=\operatorname{diag} .\left(b_{1}, b_{2}, \ldots, b_{m}\right) \in R^{m \times m}: \text { 駆動系粘性行列 } \\
& b_{i}: i \text { 番目駆動部の粘性定数 }\left(b_{i}>0\right) \\
& \alpha_{t}=\left(\alpha_{t 1}, \alpha_{t 2}, \ldots, \alpha_{t m}\right)^{T} \in R^{m}: \text { ワヤ張力ベクトル } \\
& \alpha_{t i}: i \text { 番目ワイヤの張力 } \\
& \tau=\left(\tau_{1}, \tau_{2}, \ldots, \tau_{m}\right)^{T} \in R^{m}: \text { 駆動系発生力ベクトル } \\
& \tau_{i}: i \text { 番目駆動部の発生力 }
\end{aligned}
$$

とする。一方, 制御対象物のダイナミクスは, 位置姿勢べクト ルを $x$ とすれば次式となる.

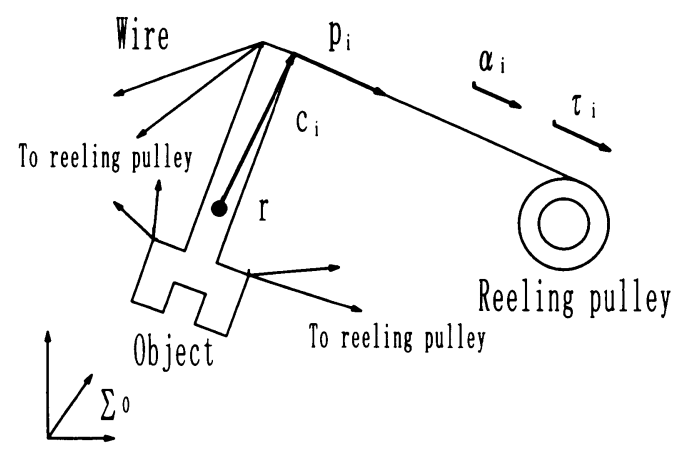

Fig. 1 Definition of coordinate systems

$$
M_{0} \ddot{x}+\left(\frac{1}{2} \dot{M}_{0}+S_{0}(x, \dot{x})\right) \dot{x}+g_{0}=f
$$

上式において，

$M_{0} \in R^{n_{0} \times n_{0}}:$ 基準座標系 $\Sigma_{0}$ から見た慣性行列

$S_{0}(x, \dot{x}) \in R^{n_{0} \times n_{0}}:$ 歪対称行列

$\dot{x}=\left(\begin{array}{ll}\dot{r}^{T} & \omega^{T}\end{array}\right)^{T} \in R^{n_{0}}$

$\omega$ : 角速度ベクトル

$r:$ 制御対象物重心位置

$g_{0} \in R^{n_{0}}:$ 重力項

$f \in R^{n_{0}}$ : 制御対象物に加わる力とモーメント

とする. Fig. 1 に示すように, 制御対象物に加わる力とモーメ ント $f$ はワイヤ張力ベクトル $\alpha_{t}$ によって発生する.ここで $f$ は次式で与えられる。

$$
f=W \alpha_{t}
$$

ただし，

$$
\begin{aligned}
& W=\left[w_{1}, w_{2}, \ldots, w_{m}\right] \in R^{n_{0} \times m}: \text { ワイヤ行列 } \\
& w_{i}=\left[\begin{array}{c}
p_{i} \\
c_{i} \times p_{i}
\end{array}\right] \in R^{n_{0}} \\
& p_{i}: \text { ワイヤ方向単位ベクトル } \\
& c_{i}: \text { 制御対象物の重心からワイヤ装着位置までのベクトル } \\
& \times: \text { ベクトル積 }
\end{aligned}
$$

とし，Wをワイヤ行列， $w_{i}$ をワイヤベクトルと定義する. 式 （3）より, ワイヤ行列 $W$ は制御対象物に加わる力とモーメン トベクトル $f$ とワイヤ張力ベクトル $\alpha_{t}$ とを関係付ける行列で あり，以下の関係が成立する。

$$
\alpha_{t}=W^{+} f+\left(I-W^{+} W\right) k_{e}
$$

$W^{+}$は $W$ の疑似逆行列であり, $W^{+}=W^{T}\left(W W^{T}\right)^{-1}$ で 定義される。また, 右辺第 2 項は内力を意味し, $k_{e} \in R^{m}$ は任意のべクトルである．Vector Closure を満足すれば， $\left(I-W^{+} W\right) k_{e}>0$ とでき, $\alpha_{t}$ の各要素が正となる.

\section{3. 作業座標系制御法}

\section{1 安定解析}

次に制御入力の説明をする. 対象物の目標位置姿勢を $x_{d}$ と したとき, 外界センサなどで計測した $x$ を利用して, 制御入力 $\tau$ を次式で与える。

$$
\tau=W^{+}\left(K_{p}\left(x_{d}-x\right)-K_{v} \dot{x}+g_{0}\right)+v
$$


$K_{p}, K v \in R^{n_{0} \times n_{0}}:$ フィードバックゲイン

ここで, Vector Closure を満たす範井では, 行列 $W W^{T}$ は常 に正則となる。また， $v$ はワイヤ間の内力を生む入力であり， 常に以下の条件を満たす。

$$
W v=0
$$

ワイヤ長さベクトル $q$ と位置姿勢ベクトル $x$ の幾何学的関 係である逆運動学に注目すると，

$$
\dot{q}=W^{T} \dot{x}
$$

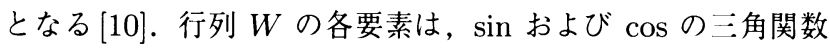
であるので微分可能であり，

$$
\ddot{q}=W^{T} \ddot{x}+\dot{W}^{T} \dot{x}
$$

が成立する。結局，上式と式（1）（2）（3）（5）（6）より，作 業座標系制御法のシステムダイナミクスとして次式を得る.

$$
\begin{aligned}
& \left(M_{0}+W M W^{T}\right) \ddot{x}+\left(W M \dot{W}^{T}+W B W^{T}+K_{v}\right) \dot{x} \\
& +h_{0}-K_{p}\left(x_{d}-x\right)=0
\end{aligned}
$$

ただし上式において $h_{0}=\left(\frac{1}{2} \dot{M}_{0}(x)+S_{0}(x, \dot{x})\right) \dot{x}$ とする. ここで制御方式によって, 安定かつ $x$ が目標位置 $x_{d}$ に収束す ることをリアプノフの安定性を用いて証明する. スカラ関数 $V$ を次式で与える.

$$
V=\frac{1}{2} \dot{x}^{T}\left(M_{0}+W M W^{T}\right) \dot{x}+\frac{1}{2}\left(x_{d}-x\right)^{T} K_{p}\left(x_{d}-x\right)
$$

$M_{0}+W M W^{T}>0, K_{p}>0$ より, スカラ関数 $V$ はリアプノ フ関数の候補となる. スカラ関数 $V$ をシステムの解軌道に沿っ て時間微分し, 良く知られているように $\dot{x}^{T}\left(\frac{1}{2} \dot{M}_{0} \dot{x}-h_{0}\right)=0$ の関係 [9]を用いれば次式を得る。

$$
\dot{V}=-\dot{x}^{T}\left(K_{v}+W B W^{T}\right) \dot{x} \leq 0
$$

したがって， $\dot{V}=0$ の最大不変集合に収束する。この場合は $\ddot{x}=\dot{x}=0$ である.これらをダイナミクス代入することにより $K_{p}\left(x_{d}-x\right)=0$ に収束することがわかる.よって $t \rightarrow \infty$ の とき, $x \rightarrow x_{d}$ となり, 手先は目標位置に収束し, 駆動系発生 力 $\tau$ は式 $(12)$ に収束する.

$$
\tau=W^{+} g_{0}+v
$$

\section{4. 作業座標系制御法におけるロバスト性}

作業座標系制御法は外界センサなどを用いて対象物の位置姿 勢を計測し, フィードバックする。しかしながら, 駆動部の取 り付け誤差やワイヤの取り付け誤差などから十分に正確なワイ ヤ行列を得ることは困難である場合も多い。そこでワイヤ行列 のロバスト性を論じる. 以下では行列 $A$ の推定量を $\hat{A}$ とする. ワイヤ行列に推定量を用いた作業座標系フィードバックの制御 入力を示す.

$$
\tau=\hat{W}^{+}\left(-K_{p} \Delta x-K_{v} \dot{x}+\hat{g}_{0}\right)+\hat{J}_{m}^{T} k_{d}
$$

ここで, $\left(I-\hat{W}^{+} \hat{W}\right)=\hat{J}_{m}^{T}, \Delta x=x-x_{d}$ であり, $k_{d}$ は内力 を発生するために設定するべクトルである。 また，式（13）に

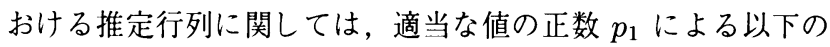
有界性を仮定する。

$$
\left\|W^{+}-\hat{W}^{+}\right\| \leq p_{1}
$$

式 (1)（4）（13）より,

$$
\begin{array}{r}
M \ddot{q}+B \dot{q}+\hat{W}^{+}\left(K_{p} \Delta x+K_{v} \dot{x}-\hat{g_{0}}\right) \\
=-W^{+} f+J_{m}^{T} \delta k-\delta_{J m} k_{d}
\end{array}
$$

となる．ただし， $\delta k=k_{d}-k_{e}, \delta_{J m}=J_{m}^{T}-\hat{J}_{m}^{T}$ とする.こ こでリアプノフ関数としてスカラ関数 $V$ を考える.

$$
\begin{aligned}
V= & \frac{1}{2} \dot{q}^{T} M \dot{q}+\alpha \Delta x^{T} W M \dot{q}+\frac{1}{2} \dot{x}^{T} M_{0} \dot{x} \\
& +\alpha \Delta x^{T} M_{0} \dot{x}+\frac{1}{2} \Delta x^{T}\left(K_{p}+\alpha K_{v}\right) \Delta x
\end{aligned}
$$

式（16）は式（17）のように変形できる.

$$
\begin{aligned}
V= & \frac{1}{4} \dot{q}^{T} M \dot{q}+\frac{1}{4} \dot{x}^{T} M_{0} \dot{x}+\frac{\alpha}{2} \Delta x^{T} K_{v} \Delta x \\
& +\frac{1}{4}\left(\dot{q}+2 \alpha W^{T} \Delta x\right)^{T} M\left(\dot{q}+2 \alpha W^{T} \Delta x\right) \\
& +\frac{1}{4}(\dot{x}+2 \alpha \Delta x)^{T} M_{0}(\dot{x}+2 \alpha \Delta x) \\
& +\Delta x^{T}\left(\frac{1}{2} K_{p}-\alpha^{2}\left(W M W^{T}+M_{0}\right)\right) \Delta x
\end{aligned}
$$

フィードバックゲインを適当な大きさに与え， $\alpha$ を小さす れば,

$$
K_{p}>2 \alpha^{2}\left(W M W^{T}+M_{0}\right)
$$

を満足し, スカラ関数 $V$ は正定值となり, リアプノフ関数の 候補となる。一方，この時間微分に関して次式を得る.

$$
\begin{aligned}
-\frac{d V}{d t}= & \dot{x}^{T}\left(K_{v}+W B W^{T}\right) \dot{x}+\alpha \Delta x^{T} K_{p} \Delta x \\
& -\dot{x}^{T} \Gamma K_{v} \dot{x}-\alpha \Delta x^{T} \Gamma K_{p} \Delta x \\
& -\dot{x}^{T} \Gamma K_{p} \Delta x-\alpha \Delta x^{T} \Gamma K_{v} \dot{x} \\
& +\alpha h+z^{T} \delta_{1}
\end{aligned}
$$

$$
\begin{aligned}
h= & \Delta x^{T}\left(W B W^{T}-\frac{1}{2} \dot{M}_{0}+S_{0}(x, \dot{x})-\dot{W} M W^{T}\right) \dot{x} \\
& -\dot{x}^{T}\left(W M W^{T}+M_{0}\right) \dot{x}
\end{aligned}
$$

$$
\begin{gathered}
\Gamma=W\left(W^{+}-\hat{W}^{+}\right), \\
\delta_{1}=\left[\begin{array}{c}
W \\
\alpha W
\end{array}\right] \delta, \\
z=\left[\dot{x}^{T}, \Delta x^{T}\right]^{T} \\
\delta_{w p}=W^{+}-\hat{W}^{+}, \quad \delta_{g}=g_{0}-\hat{g_{0}} \\
\delta=\delta_{J m} k_{d}+\delta_{w p} g_{0}+\hat{W}^{+} \delta_{g}
\end{gathered}
$$

式（19）より 


$$
\begin{aligned}
-\frac{d V}{d t} \geq & \left(\lambda_{\min }\left[K_{v}+W B W^{T}\right]-p_{1} b_{W} \lambda_{\max }\left[K_{v}\right]\right)\|\dot{x}\|^{2} \\
& +\alpha\left(\lambda_{\min }\left[K_{p}\right]-p_{1} b_{W} \lambda_{\max }\left[K_{p}\right]\right)\|\Delta x\|^{2} \\
& -p_{1} b_{W}\left(\lambda_{\max }\left[K_{p}\right]+\alpha \lambda_{\max }\left[K_{v}\right]\right)\|\dot{x}\|\|\Delta x\| \\
& -\alpha|h|-\|z\|\left\|\delta_{1}\right\|
\end{aligned}
$$

上式において $b_{W}$ は $W$ のノルムとする，ところでワイヤ行列 $W$ を構成するワイヤベクトル $w_{i}$ は $\sin , \cos$ の三角関数でで きており有界である。ささらに，位置変化 $\Delta x$ はVector Closure 内でのみ動作することとすれば有界となる。そこで，次式を満 たす定数 $c_{0}, c_{1}$ が存在する.

$$
\alpha|h| \leq \alpha c_{0}\|\dot{x}\|^{2}+\alpha c_{1}\|\Delta x\|^{2}
$$

また，

$$
-\frac{1}{2}\left(\|\dot{x}\|^{2}+\|\Delta x\|^{2}\right) \leq-\|\Delta x\|\|\dot{x}\|
$$

であるから，結局次式を得る。

$$
\begin{aligned}
& -\frac{d V}{d t} \geq\left(\lambda_{\min }\left[K_{v}\right] k_{1}-\alpha c_{0}\right)\|\dot{x}\|^{2} \\
& \quad+\left(\alpha \lambda_{\min }\left[K_{p}\right] k_{2}-\alpha c_{1}\right)\|\Delta x\|^{2}-\|z\|\left\|\delta_{1}\right\|
\end{aligned}
$$

$$
\begin{aligned}
k_{1}= & +\frac{\lambda_{\min }\left[W B W^{T}\right]}{\lambda_{\min }\left[K_{v}\right]} \\
& -p_{1} b_{W}\left(\frac{\left(1+\frac{\alpha}{2}\right) \lambda_{\max }\left[K_{v}\right]}{\lambda_{\min }\left[K_{v}\right]}+\frac{\lambda_{\max }\left[K_{p}\right]}{2 \lambda_{\min }\left[K_{v}\right]}\right)
\end{aligned}
$$

$$
k_{2}=1-p_{1} b_{W}\left(\frac{\left(1+\frac{1}{2 \alpha}\right) \lambda_{\max }\left[K_{p}\right]}{\lambda_{\min }\left[K_{p}\right]}+\frac{\lambda_{\max }\left[K_{v}\right]}{2 \lambda_{\min }\left[K_{p}\right]}\right)
$$

式 (26) において, ワイヤ疑似逆行列 $W^{+}$の推定值と真值と の誤差ノルム $p_{1}$ が

$$
\begin{gathered}
p_{1}<\frac{1+\frac{\lambda_{\min }\left[W B W^{T}\right]}{\lambda_{\min }\left[K_{v}\right]}}{b_{W}\left(\frac{\left(1+\frac{\alpha}{2}\right) \lambda_{\max }\left[K_{v}\right]}{\lambda_{\min }\left[K_{v}\right]}+\frac{\lambda_{\max }\left[K_{p}\right]}{2 \lambda_{\min }\left[K_{v}\right]}\right)} \\
p_{1}<\frac{1}{b_{W}\left(\frac{\left(1+\frac{1}{2 \alpha}\right) \lambda_{\max }\left[K_{p}\right]}{\lambda_{\min }\left[K_{p}\right]}+\frac{\lambda_{\max }\left[K_{v}\right]}{2 \lambda_{\min }\left[K_{p}\right]}\right)}
\end{gathered}
$$

の 2 式を同時に満足する大きさを持てば， $k_{1}>0$ かつ $k_{2}>0$ となる。したがって，十分大きなフォードバックゲイン $K_{p}$, $K_{v}$ によって

$$
\lambda_{\min }\left[K_{v}\right] k_{1}-\alpha c_{0}>0, \quad \alpha \lambda_{\min }\left[K_{p}\right] k_{2}-\alpha c_{1}>0
$$

とすることができ, 次式を得る.

$$
-\frac{d V}{d t} \geq l\|z\|^{2}-\|z\|\left\|\delta_{1}\right\|
$$

ここに

$$
l=\min \left(\lambda_{\min }\left[K_{v}\right] k_{1}-\alpha c_{0}, \alpha \lambda_{\min }\left[K_{p}\right] k_{2}-\alpha c_{1}\right)
$$

とする．結局，もし

$$
\|z\|>\frac{\left\|\delta_{1}\right\|}{l}
$$

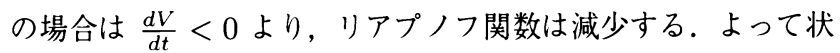
態量 $\|z\|$ は減少する. しかしながら $\|z\|$ が減少して,

$$
\|z\|<\frac{\left\|\delta_{1}\right\|}{l}
$$

となると, $\frac{d V}{d t}>0$ となることもあり得るが, そのとき $V$ は増 加し, 状態量 $\|z\|$ も増加する. 増加した状態量が式 (34) を 満たすと, $\|z\|$ は再び減少する.したがって終局的有界性が 主張でき, システムはある領域にとどまることが示される。こ こで式 (32) より, 誤差がゼロの場合は $\delta_{1}$ がゼロとなり目標 位置へ収束する。また，フィードバックゲインの増加が誤差を 減少させることも理解できる。

\section{4 本ワイヤロボットによる実験}

\subsection{4 本ワイヤ 3 自由度ロボット}

前章では，作業座標系制御のロバスト性が終局有界という形 で示された。しかし，他のこの種の証明方法と同様に，前章で の結果の式 (29)（30）は十分条件として厳しすぎるとも考え られる。すなわち, 式 $(29)$ （30）を満足しなくとも，実際に は安定性が保証できることも予想される。そこで，本章では簡 単な実験システムによって実用上のロバスト性を明らかにする.

4 本ワイヤを用いた平面 3 自由度ロボットを用い, パラレル ワイヤ駆動システムの作業座標系制御法の実験を行った。 4 本 ワイヤ 3 自由度ロボットの概要を Fig. 2 に示す。このロボット は $\mathrm{X}-\mathrm{Y}$ 平面内の回転と並進の 3 自由度を制御可能である。制 御対象物である長方形状の金属プレートには上・下端の 2 点か ら放射状に各点 2 本ずつ, 計 4 本のワイヤが張られている. 金 属プレートのワイヤ端点間は $50[\mathrm{~mm}]$ であり, 各ワイヤはガイ

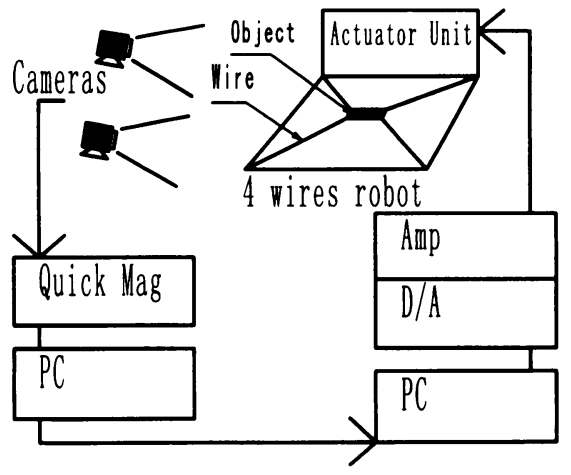

Fig. 24 wires robot system 


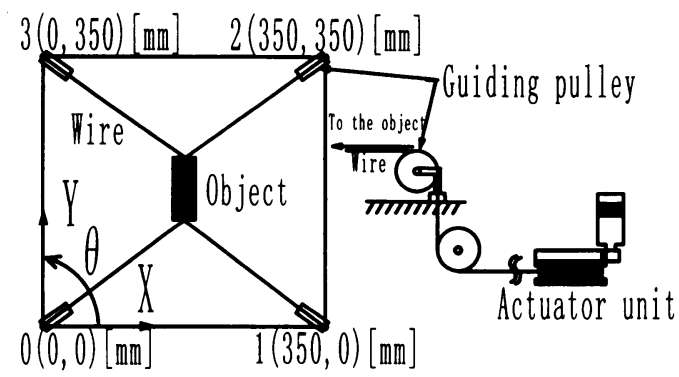

Fig. 34 wires robot with 3 D.O.F.

ドプーリを介してアクチュエータ内のプーリによって巻き取ら れている.アクチュエータはギア (ギア比 1:4), $60[\mathrm{~W}]$ モー 夕, 内径 $45[\mathrm{~mm}]$ のプーリで構成されている. Fig. 3 に示すよ うに，制御平面内のガイドプーリは一辺を $350[\mathrm{~mm}]$ とする正 方形の各頂点に位置する。ガイドプーリは鉛直軸に自由に回転 し，ワイヤの方向に追従する。 ガイドプーリの首振りに対して， $\mathrm{X}-\mathrm{Y}$ 平面上の拈りるワイヤ出口は常に一定に保たれてワイヤ は常に $\mathrm{X}-\mathrm{Y}$ 平面上にあるように設計されている。

外界センサとしては株式会社応用計測研究所 (OKK INC.) の Quick MAG システムを用いている. Quick MAG システム は 2 台のカメラによって計測対象物の三次元計測が可能であり, Quick MAG 制御用コンピュータの出力によってロボット制御 用コンピュー夕に計測位置が転送される．4本ワイヤロボット システムでは制御対象物に 2 点の位置計測用のマーカーを配置 し, リアルタイムでマーカー 2 点の三次元計測を行う. 2 点の 值はロボット制御用コンピュータに取り込まれる,この際, 2 点 の鉛直方向（Z 軸）の位置デー夕は用いず， $\mathrm{X}-\mathrm{Y}$ 平面内のデー 夕だけを用いて制御対象物の位置姿勢 $(\mathrm{x}, \mathrm{y}, \theta)$ が計算されるこ ととなる。本システムの Quick MAG の分解能は $0.3[\mathrm{~mm}]$ 程 度である。

\section{2 位置制御実験}

ここでは以下のワイヤ疑似逆行列を用いて作業座標系による 位置制御を試みた。なお，実験では水平面内の運動であるので， すべての場合について重力補償項は利用していない.

\section{$W^{+}$: 真值ワイヤ疑似逆行列}

外界センサによって, 制御対象物の位置姿勢が計測され, 正し いと思われるワイヤ行列によって制御入力式（5）を与えられ る場合の位置制御である。釣り合い内力はリアルタイムで計測 された物体の位置姿勢から実時間で更新している。

$\hat{W}^{+}$: 推定ワイヤ疑似逆行列

アクチュエータ位置に誤差を含む場合の位置制御とする。今回 は Table 1 に示すようにワイヤ出口の真值に対して, 意図的 にワイヤ行列に誤差を与えた。釣り合い内力は式（13）のよう に, 目標位置での推定值から算出される推定釣り合い内力を与 えている.

$W_{c}^{+}:$定数ワイヤ疑似逆行列

リアルタイムにワイヤ行列を更新せず，ワイヤ行列を初期状態 で与えられた定数として位置制御を行う。定数のワイヤ疑似逆 行列 $W_{c}^{+}$を用いる利点としては, ソフトウェアの簡略化が上 げられる。
Table 1 Coordinates of wire exit points $(\mathrm{X}, \mathrm{Y})$

\begin{tabular}{|c|c|c|c|c|}
\hline & 0 & 1 & 2 & 3 \\
\hline Correct & $0,0[\mathrm{~mm}]$ & $350,0[\mathrm{~mm}]$ & $350,350[\mathrm{~mm}]$ & $0,350[\mathrm{~mm}]$ \\
\hline Estimated & $0,70[\mathrm{~mm}]$ & $280,0[\mathrm{~mm}]$ & $350,280[\mathrm{~mm}]$ & $70,350[\mathrm{~mm}]$ \\
\hline
\end{tabular}

Table 2 Steady-state errors of position experiments

\begin{tabular}{|l|c|c|c|c|c|c|}
\hline \multirow{4}{*}{} & \multicolumn{2}{|c|}{$(1)$} & \multicolumn{2}{c|}{ (2) } & \multicolumn{2}{c|}{ (3) } \\
\cline { 2 - 7 } & \multicolumn{2}{|c|}{ Vector Closure } & \multicolumn{2}{c|}{ Vicinity of boundary } & \multicolumn{2}{c|}{ Boundary of V.C. } \\
\cline { 2 - 7 } & PD & PID & PD & PID & PD & PID \\
\hline$W^{+}$ & $1.5[\mathrm{~mm}]$ & $0.4[\mathrm{~mm}]$ & $2.3[\mathrm{~mm}]$ & $0.4[\mathrm{~mm}]$ & $2.5[\mathrm{~mm}]$ & $2.5[\mathrm{~mm}]$ \\
\hline$\hat{W}^{+}$ & $1.6[\mathrm{~mm}]$ & $0.5[\mathrm{~mm}]$ & $2.8[\mathrm{~mm}]$ & $1.1[\mathrm{~mm}]$ & $3.7[\mathrm{~mm}]$ & $3.2[\mathrm{~mm}]$ \\
\hline$W_{c}^{+}$ & $1.7[\mathrm{~mm}]$ & $0.6[\mathrm{~mm}]$ & $2.1[\mathrm{~mm}]$ & $1.0[\mathrm{~mm}]$ & $3.0[\mathrm{~mm}]$ & $3.0[\mathrm{~mm}]$ \\
\hline$W^{T}$ & $2.1[\mathrm{~mm}]$ & $0.8[\mathrm{~mm}]$ & $2.1[\mathrm{~mm}]$ & $0.9[\mathrm{~mm}]$ & $4.3[\mathrm{~mm}]$ & $3.5[\mathrm{~mm}]$ \\
\hline
\end{tabular}

\section{$W^{T}:$ ワイヤ転置行列}

ワイヤ行列の疑似逆行列が $R^{m \times n_{0}}$ であるのに注目し, 疑似逆 行列 $W^{+}$の代わりに転置行列 $W^{T}$ を用いる。これは $W^{T}$ を $W^{+}$の推定量として与える方法である. 定数ワイヤ疑似逆行列 と同様, ソフトウェアの簡略化の面で利点がある.

本実験では上記 4 種類のワイヤ行列を用いた制御法に対し， $(175,175,0)$ を初期状態とし以下の三つの目標位置に対してそ れぞれ PD 制御と PID 制御を行った。

\section{(1) Vector Closure 内}

$(105,175,0)$ : Vector Closure の境界条件から十分遠い目標位置 (2) Vector Closure 境界線近傍

$(30,175,0)$ : Vector Closure の境界条件近傍の目標位置

\section{(3) Vector Closure 境界線上}

$(0,175,0)$ : Vector Closureの境界線上の目標位置

以上に示される制御方法, 初期位置, 目標位置においては, 式 (29)（30）で与えられるパラメー夕 $p_{1}$ は, 式 (14) で与え られる奏際のワイヤ行列の誤差の 10 分の 1 程度となっている. すなわち, 理論的に保証できる範囲よりも 10 倍大きな誤差を 与えている.

本システムのように最少ワイヤ本数 $n+1$ 本を用いて制御を 行う場合は, 釣り合い内力ベクトルの各成分比率は一定であり, ベクトルの大きさのみ変更可能である [8]. Vector Closureの 境界線やその近傍では釣り合い内力が現実では実現できないよ うな極端に大きな值となる可能性がある。そこで本実験では， 釣り合い内力の各ワイヤ成分がある值以上にならないように， 内力ベクトルの係数を与えている. Vector Closure 境界線上に おける釣り合い内力は, Fig. 3 の 0 番目, 3 番目のアクチュエー 夕に通じるワイヤに対して同じゼロ以外の適当な張力を与え, 1 番目, 2 番目のワイヤ張力を $0[\mathrm{~N}]$ に設定した. なお, フィー ドバックゲインの值は通常の PD, PID 制御のチューニング方 法により決定した。

それぞれの実験の定常状態での位置誤差を Table 2 に示 す. PD 制御を用いた場合では, Vector Closure 内で 1.5 $2.1[\mathrm{~mm}]$, 境界線近傍で $2.1 \sim 2.8[\mathrm{~mm}]$, 境界線上では 2.5 $4.3[\mathrm{~mm}]$ の定常偏差が確認された。誤差の主な原因は疑似逆 行列や釣り合い内力の䛊差量と摩擦であると考えられる。これ に対し, 本論文では理論的に収束性を証明していないが, 積分 


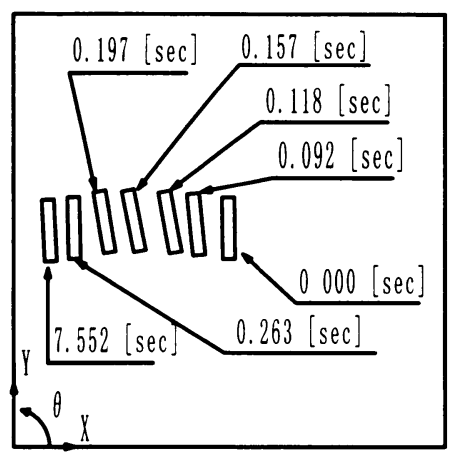

Fig. 4 Trajectory on $W^{+}$PID control

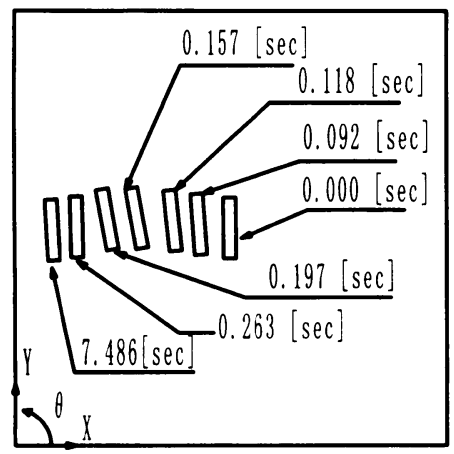

Fig. 5 Trajectory on $\hat{W}^{+}$PID control

項を加えた PID 制御の場合では定常偏差が減少され, Vector Closure 内で $0.4 \sim 0.8[\mathrm{~mm}]$, 境界線近傍で $0.4 \sim 1.1[\mathrm{~mm}]$, 境 界線上では $2.5 \sim 3.5[\mathrm{~mm}]$ となった。なお，同一実験システム で, 従来用いたワイヤ座標系制御法 [8]を利用した場合では, 作 業座標系制御法の場合と比較して外界センサの計測で 2 2 倍 程度の位置誤差となったことを報告しておく。

また，目標値を $(30,175,0)$ とした場合の各ワイヤ行列の PID 制御に拈ける対象物の軌道を Fig. 4 7 に示す．誤差を含むワ イヤ行列を用いる場合では，理論では式（34）（35）のように 状態量がある值の範囲内に収束することは証明しているが，手 先位置が静止することまでは保証していない.しかしながら， 実システムでは適当な值に収束している。 また，目標位置近傍 までは，高速に運動していることが実験結果からわかる，一方 で，I 動作によって位置精度を高めるために，多くの時間を費 やしている。したがって, 位置精度と速度の利用目的によって 使い分ける必要があろう。

本実験ではシンプルなケースとして重力補償項を必要としな い例を取り扱い，その誤差について言及した。しかし，重力の 影響が大きい系については，ワイヤの弾性要素が無視できなく なるなどの理由から, 系の挙動が不安定になる場合も考えられ る.それらの実験結果については別の機会に報告する.

\section{3 力制御実験}

ワイヤ行列はワイヤ張力空間を手先力空間に変換する。した がって制御入力を次式にすることでフィードフォワードの力制 御への拡張が可能となる.

$$
\tau=W^{+}\left(f_{d}+g_{0}\right)+v
$$

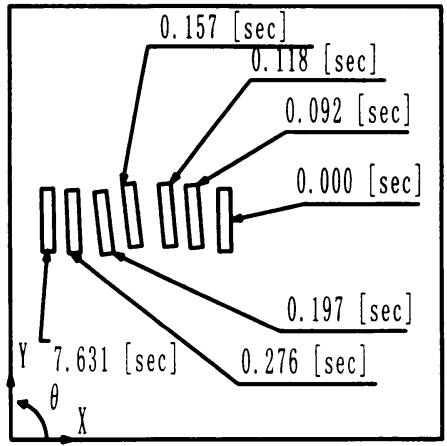

Fig. 6 Trajectory on $W_{c}^{+}$PID control

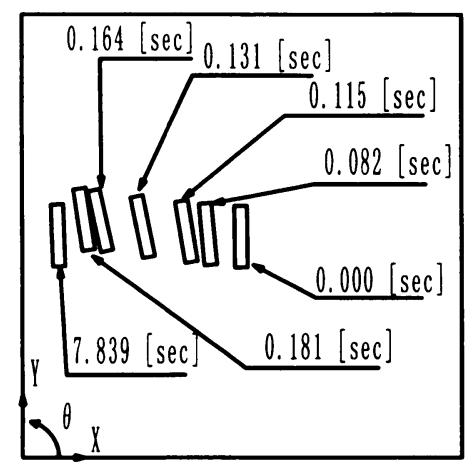

Fig. 7 Trajectory on $W^{T}$ PID control

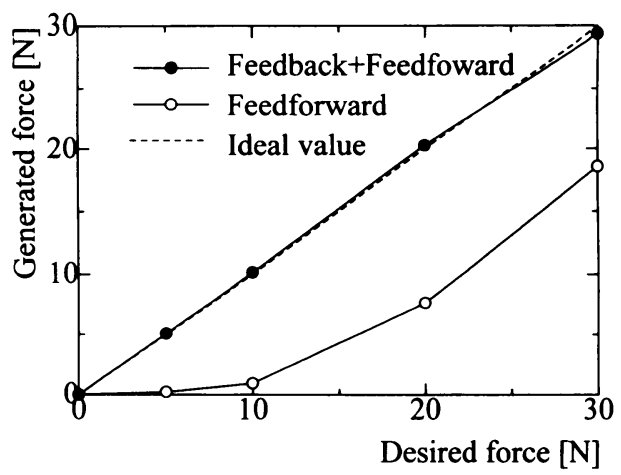

Fig. 8 Experimental results of force control (X axis)

$f_{d}$ は手先目標力とし，一定值とする，位置制御実験と同様の システムを用いて力制御実験を行った．Fig. 8，9 の○印に フィードフォワード入力の実験結果を示す.ここでは手先座標 (175,175,0)において，x,y 方向にそれぞれ力制御を行ったも のである. 各方向とも目標力には達していない。これも, アク チュエータやガイドプーリの摺動部の摩擦が主な原因と考えら れる.そこで, 同様の実験を式（37）のようにフィードバック を含めた力制御実験を行った。 $K_{f}$ はフィードバックゲインで ある. Fig. 8, 9 の○印にフィードバックとフィードフォワード 併用の実験結果を示す。

$$
\tau=W^{+}\left(K_{f}\left(f_{d}-f\right)+f_{d}+g_{0}\right)+v
$$

フィードフォワードの力制御に比べ, 精度の良い制御が可能と 


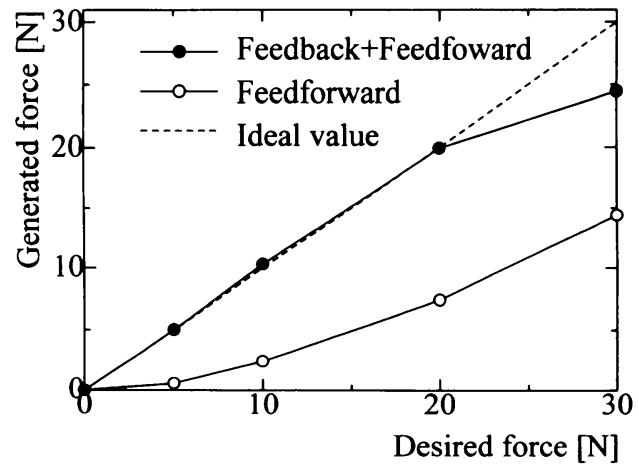

Fig. 9 Experimental results of force control ( $\mathrm{Y}$ axis)

なっていることがわかる. しかしながら，y 方向の目標力 $30[\mathrm{~N}]$ では偏差が大きく存在する。これはモータの飽和が原因である と考えられる。

\section{6. おわりに}

本報告ではパラレルワイヤ駆動システムにおける作業座標系 制御法について, ワイヤ行列 $W$ の擬似逆行列 $W^{+}$を用いた 制御法を提案し，以下のことを明らかにした。

・ワイヤ行列が正しく計測される場合について, リアプノフ の方法により安定解析を行い, 手先が目標位置に収束する ことを示した。

・ワイヤ行列に誤差を含む場合について, リアプノフの方法 によりロバスト性を示し, 状態量の終局的有界性を示した. また, 外界センサを利用し, 4 本ワイヤ平面 3 自由度ロボット を用いて提案する作業座標系制御法の実験を行い, 以下のこと を示した。

- ワイヤ疑似逆行列が真值, 推定值, 定数, ワイヤ転置行 列の場合について PD 位置制御を行い, 目標值が Vector Closure 内では, 䛊差が 1.5 2.1 [mm] 程度であることを 確認した。また，PID 制御を用いることで誤差が 0.4 $0.8[\mathrm{~mm}]$ 程度に減少することを確認した. さらに, Vector Closure の境界線近傍や境界線上における位置精度を検証 した.

・フィードバックとフィードフォワードの力制御を行い, フィー ドバックを用いた力制御ではモータ出力が飽和しない限り 良好な制御が可能であることを確認した。

本論文で行った作業座標系のロバスト性解析では十分条件とし て理論的に保証している範囲は極めて狭いように思われる。そ こで今回の推定ワイヤ行列を用いる実験では意図的に大きな䛊 差を与えた。実験結果から, システムはワイヤ疑似逆行列の誤 差に対して非常にロバストであることが示された。それ故, 理 論的に厳密に補償できる範囲を現実に近づけることが今後の課
題の一つである。また, 証明では PD 制御の解析しか行ってい ないが, PID 制御については参考文献 [11]のように外乱項を定 数とすれば同様の証明ができると思われ, 今回は紙面の都合で 割愛した。

実際にパラレルワイヤ駆動の大型システムなどに作業座標系 制御を用いる場合ではワイヤ出口の座標に誤差が含まれる状態 でも，ワイヤの方向ベクトルに今回の実験のような極端に大き な誤差を含むことは考えにくい，したがって他の実システムで も精度の良い位置制御が可能であると思われる。また，場合に よってはワイヤ疑似逆行列 $W^{T}$ を用いず, 定数ワイヤ疑似逆 行列 $W_{c}^{T}$ やワイヤ転置行列 $W^{T}$ を用いることによってソフト ウェアを簡略化できることが，実験結果から示された。これら の実用的意義は大きいと考えられる。

本論文では, 解析を簡単にするためにワイヤ駆動系には弾性 要素がないとして取り扱った。しかしながら，実際には非線型 剛性を有しており [6], 今後はワイヤの弾性要素を考慮したシス テムにいての解析を行う必要がある。

\section{参 考 文 献}

[1] V.D. Nguyen: "Constructing Force-Closure Grasp in 3D," Proc. of the 1987 IEEE Int. Conf. on Robotics and Automation, pp.240-245, 1987.

[2] 桶口俊郎, 明愛国：“ワイヤー駆動を利用したスタッカークレーンの 開発一第 3 報フィードフォワード制御の適用—”, 精密工学会秋季大 会学術講演会講演論文集, pp.503-504, 1988.

[3] 大隅久, 新井民夫, 浅間一：“3 本ワイヤを有する 7 自由度クレーンの 開発（第 1 報)”, 精密工学会誌, vol.59, no.5, pp.767-772, 1993.

[4] S. Kawamura and K. Ito: "A New Type of Master Robot for Teleoperaiton Using A Radial Wire Drive System," Proc. of the 1993 IEEE/RSJ Int. Conf. on Intelligent Robots and Systems, vol.1, pp.55-60, 1993.

[5] S. Kawamura, W. Choe, S. Tanaka and S.R. Pandian: "Development of an Ultrahigh Speed Robot FALCON using Wire Drive System," IEEE Int. Conf. on Robotics and Automation, pp.215-220, 1995.

[6] 川村貞夫, 崔源, 田中訓, 木野仁：“パラレルワイヤ駆動方式を用い た超高速ロボットFALCONの開発”, 日本ロボット学会誌, vol.15, no.1, pp.82-89, 1997.

[7] H. Kino, H. Miyazono, C. Won and S. Kawamura: "Realization of Large Work Space using Prallel Wire Drive Robots," 2nd Asian Control Conference, vol.3, pp.591-594, 1997.

[8] 川村貞夫, 木野仁, 崔源, 勝田兼: “パラレルワイヤ駆動システム に㧍けるワイヤ座標系制御法”, 日本ロボット学会誌, vol.16, no.4, pp.546-552, 1998.

[9] 有本卓：ロボットの力学と制御. 朝倉書店, 1991.

[10] 大隅久, 沈干思, 新井民夫：“ワイヤ懸垂系における操り指標”, 日 本ロボット学会誌, vol.12, no.7, pp.1049-1055, 1994.

[11] S. Arimoto: Control Theory of Non-linear Mechanical Systems. CLARENDON PRESS OXFORD, 1996.

[12] C.C. Cheah, H.Y. Han, S. Kawamura and S. Arimoto: "Grasping and Position Control for Multi-fingered Robot Hands with Uncertain Jacobian Matrices," pp.2403-2408, IEEE, R\&A Proceedings, 1998. 


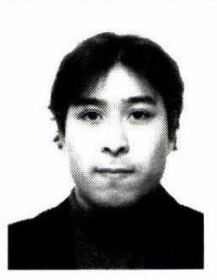

木野 仁 (Hitoshi Kino)

1971 年 3 月 13 日生. 1994 年立命館大学理工学 部機械工学科卒業. 1996 年同大学大学院理工学研 究科修士課程修了. 同年同大学大学院博士後期課 程に入学. 1997 年 3 月退学後, 1997 年 4 月より 䋦賀医科大学マルチメディアセンタ勤務。パラレ ルメカニズム，医療福祉ロボットなどに興味を持 ว.

(日本ロボット学会正会員)

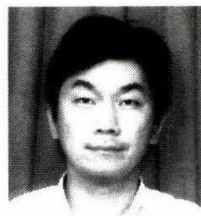

\section{Chien Chern Cheah}

received the Ph.D. in Electrical Engineering from Nanyang Technological University, Singapore in 1996. He was a teaching assistant in the University from 1991 to 1996 , and was a research fellow in Ritsumeikan University, Japan from 1996 to 1998. Presently, he is an assistant professor in the Nanyang Technological University.

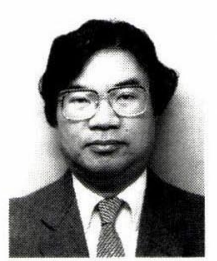

\section{有本 卓 (Suguru Arimoto)}

1936 年 8 月 3 日生. 1959 年京都大学理学部卒業·沖 電気工業 KK, 東京大学助手, 講師を経て 1968 年 大阪大学基礎工学部助教授, 1973 年同教授, 1988 年東京大学工学部教授, 1997 年立命館大学理工学 部ロボティクス学科教授となり現在に至る. 工学博 士. ロボティクス, 制御理論, 信号処理, 情報理論 の研究に従事. 日本機械学会, 情報処理学会, 計測自動制御学会など の会員. IEEEの Fellow 会員.

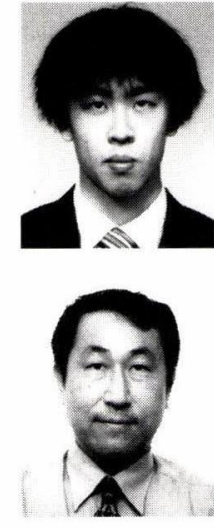

矢部 茂 (Shigeru Yabe)

1976 年 3 月 2 日生. 1999 年立命館大学理工学部 機械工学科卒業. 同年同大学大学院理工学研究科 情報システム学専攻修士課程に入学. 現在に至る. 宇宙ロボットの開発に興味を持つ。

\section{川村貞夫 (Sadao Kawamura)}

1956 年 7 月 10 日生. 1981 年大阪大学基礎工学部 生物工学科卒業. 1986 年同大学大学院機械工学科 博士課程修了. 同年同大学同学科助手. 1987 年立 命館大学理工学部機械工学科助教授を経て, 1995 年同大学同学科教授. 1996 年同大学ロボティクス 学科教授. 学習制御, 生体ロボティクス等の研究 に従事. 日本機械学会, 計測自動制御学会, システム制御情報学会, IEEEなどの会員.

(日本ロボット学会正会員) 